WHAT GOOD ARE BUGS?

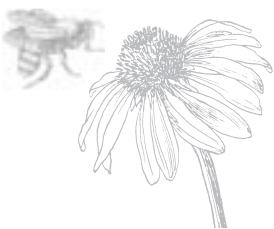





\section{G ILBERT WALDBA UER}

\section{WHAT GOOD ARE BUGS?}

INSECTS IN THE WEB OF LIFE

HARVARD UNIVERSITY PRESS

Cambridge, Massachusetts

London, England 
Copyright () 2003 by the President and Fellows of Harvard College All rights reserved

Printed in the United States of America

First Harvard University Press paperback edition, 2004

\section{Illustrations by Meredith Waterstraat}

Library of Congress Cataloging-in-Publication Data

Waldbauer, Gilbert.

What good are bugs? : insects in the web of life / Gilbert Waldbauer.

$$
\text { p. cm. }
$$

Includes bibliographical references (p.).

ISBN 0-674-01027-2 (hardcover : alk. paper)

ISBN 0-674-01632-7 (pbk.)

1. Insects-Ecology. I. Title.

QL496.4.W35 2003

595.717-dc21

2002027335 
To the naturalists who came before me, especially my teachers Aretas A. Saunders, Charles P. Alexander, William R. Horsfall, Gotftried S. Fraenkel, and Leigh E. Chadwick 
